\title{
Negative Feedback Regulation of Pulsatile Growth Hormone Secretion by Insulin-like Growth Factor I

\author{
Involvement of Hypothalamic Somatostatin
}

\author{
Martin Bermann, * Craig A. Jaffe, ${ }^{*}$ Wellington Tsai, ${ }^{*}$ Roberta DeMott-Friberg, ${ }^{\ddagger}$ and Ariel L. Barkan ${ }^{*}$ \\ *Division of Endocrinology, Department of Internal Medicine, Department of Veterans Affairs Medical Center, Wayne State University \\ Medical School, Detroit, Michigan 48101; and ${ }^{\ddagger}$ Division of Endocrinology and Metabolism, Department of Internal Medicine, \\ Department of Veterans Affairs Medical Center and the University of Michigan Medical Center, Ann Arbor, Michigan 48109
}

\begin{abstract}
To investigate the mechanisms of the negative feedback inhibition of growth hormone (GH) secretion by IGF-I, we studied parameters of $\mathrm{GH}$ pulsatility in six normal, fed men before and during a 48-h infusion of recombinant human IGF-I (rhIGF-I) (10-15 $\mathrm{\mu g} / \mathrm{kg}$ per h). Plasma levels of IGF-I increased from the baseline value of $163.5 \pm 9.3 \mu \mathrm{g} /$ liter (mean \pm SE) to a new steady state of $452.0 \pm 20.9 \mu \mathrm{g} /$ liter during the infusion. Plasma GH concentrations were measured every $10 \mathrm{~min}$ for $24 \mathrm{~h}$ during both saline and rhIGF-I infusions using a sensitive chemiluminescent assay. Overall, GH concentrations were suppressed during the rhIGF-I infusion by $85 \pm 3 \%$, mainly by attenuating spontaneous GH pulse amplitude (77 $\pm 4 \%$ suppression). The apparent GH pulse frequency was attenuated from $7.8 \pm 0.9$ to 4.7 \pm 0.6 pulses $/ 24 \mathrm{~h}(P=0.006)$. Administration of rhIGF suppressed GH responses to exogenous GH-releasing hormone by $82 \pm 3 \%$, and thyroid-stimulating hormone responses to thyrotropin-releasing hormone were also suppressed by $44 \pm 9 \%$. This constellation of hormonal effects is most compatible with the rhIGF-I-induced stimulation of hypothalamic somatostatin secretion. (J. Clin. Invest. 1994. 94:138-145.) Key words: somatotropin - somatotropin-releasing hormone - somatostatin • insulin-like growth factor I - pituitary
\end{abstract}

\section{Introduction}

Growth hormone $(\mathrm{GH})^{1}$ secretion from the pituitary gland is stimulated by periodic discharges of hypothalamic GH-releasing hormone (GHRH) and is tonically inhibited by hypothalamic somatostatin (SRIF) $(1,2)$. As is common in several

Address correspondence to Ariel L. Barkan, M.D., Division of Endocrinology and Metabolism, 3920 Taubman Center, Box 0354, University of Michigan Medical Center, Ann Arbor, MI 48109-0354.

Received for publication 20 September 1993 and in revised form 6 December 1993.

1. Abbreviations used in this paper: AUC, area under curve; CRC, Clinical Research Center; CV, coefficients of variation; GH, growth hormone; GHRH, GH-releasing hormone; i.v., intravenous; $\mathrm{M} \pm \mathrm{SE}$, mean \pm standard error; rhIGF-I, recombinant human IGF-I; SRIF, somatotropin release-inhibiting factor (somatostatin); TRH, thyrotropin-releasing hormone; TSH, thyroid-stimulating hormone.

The Journal of Clinical Investigation, Inc.

Volume 94, July 1994, 138-145 other hormonal systems, the end product of the GH effect, IGF-I, inhibits GH secretion in a negative feedback regulatory manner. The mechanism(s) of this negative feedback is complex. Studies in rats using intracerebroventricular injections of IGF-I have shown diminished amplitude of $\mathrm{GH}$ pulses in peripheral blood $(3,4)$. Intracerebroventricular administration of recombinant human IGF-I (rhIGF-I) in the GH-deficient dwarf rat increased somatostatin mRNA and decreased GHRH mRNA, but this effect was not observed with systemic infusions (5). Additionally, IGF-I has been reported to decrease GH secretion from cultured rat pituitary cells and to increase SRIF secretion from cultured rat hypothalamic cells $(6,7)$. Thus, both circulating IGF-I and locally produced (autocrine/paracrine) hypothalamic IGF-I are likely to participate in the negative feedback inhibition of GH synthesis and secretion.

Most of the information regarding these effects derives from in vivo animal models, predominantly the rat (4-7) and the sheep (8), as well as from in vitro studies involving animal pituitaries (7) or human GH-producing tumors (9). Direct studies of hypothalamic GHRH and SRIF secretion in humans are understandably impractical. Thus, the mechanisms involved in the suppression of GH secretion by IGF-I in normal humans are largely unknown.

The best evidence for the existence of this phenomenon in humans comes from the studies in patients with congenital GH insensitivity syndrome (Laron's type dwarfism). In these individuals the inability of peripheral tissues to generate IGF-I results in very low circulating levels of IGF-I and grossly elevated plasma GH concentrations. Administration of rhIGF-I to these patients suppresses GH into the normal range (10). Additional evidence is provided by the observation that a decline in circulating and, presumably, tissue IGF-I (11) associated with fasting or malnutrition is also accompanied by augmented $\mathrm{GH}$ secretion (12-14), which is promptly suppressed by rhIGF-I infusion (15). These earlier studies were able to document the existence of the negative IGF-I feedback but they did not address the potential mechanisms involved.

Since the occurrence of GH pulses likely reflects the periodic exposure of the pituitary somatotrophs to hypothalamic GHRH while the amplitude of GH pulses and, possibly, the interpulse $\mathrm{GH}$ concentrations are determined by the prevailing SRIF concentrations $(1,2,16)$, ascertainment of the parameters of GH pulsatility provides important, albeit indirect, information about hypothalamic GHRH and SRIF secretion. This paradigm has been used successfully in animal and human studies to investigate the nature of the neuroendocrine mechanisms involved in the alterations of GH secretion during puberty (17), the menstrual cycle (18), aging (19), and in such pathologic conditions as calorie deprivation (12-14), obesity (20), diabetes (21), growth delay (22), and acromegaly $(23,24)$. 
In this study, we investigated pulsatile GH secretory parameters in normally fed men before and during the infusion of rhIGF-I. We show that rhIGF-I infusion suppresses overall GH secretion, mainly by attenuating spontaneous $\mathrm{GH}$ pulse amplitude. rhIGF-I also blunts GH response to exogenous GHRH and the response of thyroid-stimulating hormone (TSH) to exogenous thyrotropin-releasing hormone (TRH). This constellation of hormonal effects is most compatible with the rhIGF-Iinduced stimulation of hypothalamic SRIF secretion.

\section{Methods}

\section{Subjects and study design}

The protocol was approved by the Institutional Review Board and the Clinical Research Center (CRC) Review committee at the University of Michigan and conducted in the University of Michigan CRC. Six healthy men, age 18-29, who did not take any medications and who were of normal height and weight (mean body mass index of $22.9 \mathrm{~kg}$ / $\mathrm{m}^{2}$ ), were studied after providing written informed consent. All had unremarkable clinical histories and physical examinations. Measurements of renal, hepatic, and hematologic function in all subjects were normal. The subjects were admitted to the CRC the evening before the actual studies and had an intravenous cannula placed anterograde in each forearm. They were allowed three daily meals throughout the study. The daily total caloric intake was $\sim 2,500 \mathrm{kcal}$, consisting of $15 \%$ protein, $25 \%$ fat, and $60 \%$ carbohydrates, with $\sim 30 \%$ of calories given at breakfast $(0700 \mathrm{~h}), \sim 30 \%$ at lunch $(1200 \mathrm{~h})$, and $\sim 40 \%$ given at dinner $(1900 \mathrm{~h})$. They were not allowed to snack between meals and were allowed to sleep only during specified night hours. Lights were on at $0630 \mathrm{~h}$ and off at $2300 \mathrm{~h}$.

On day 1, an infusion of normal saline was started at $0800 \mathrm{~h}$ at 20 $\mathrm{ml} / \mathrm{h}$ and continued until $1200 \mathrm{~h}$ the next day. Sampling for GH was done every $10 \mathrm{~min}$ from $0700 \mathrm{~h}$ on day 1 until $0800 \mathrm{~h}$ on day 2 . At $0800 \mathrm{~h}$ day 2 , a $50-\mu \mathrm{g}$ intravenous bolus of TRH (Thypinone; Abbot Laboratories, North Chicago, IL) was administered, and blood was sampled every $20 \mathrm{~min}$ for the next hour for TSH. This dose of TRH was chosen based on its submaximal ability to stimulate TSH secretion (25). At $1000 \mathrm{~h}$ an intravenous (i.v.) bolus of GHRH-44 (Bachem California, Torrance, CA) $0.33 \mu \mathrm{g} / \mathrm{kg}$ was administered, and blood for $\mathrm{GH}$ was sampled every $10 \mathrm{~min}$ for the next $2 \mathrm{~h}$. This dose of GHRH was chosen because of its ability to promote a submaximal rise in plasma $\mathrm{GH}$ $(26,27)$ and to elicit $\mathrm{GH}$ responses comparable in magnitude with the endogenous nocturnal GH pulses (28). After completion of the GHRH test, at $1200 \mathrm{~h}$ (day 2), an infusion of rhIGF-I was started at either 15 (first two subjects) or $10 \mu \mathrm{g} / \mathrm{kg}$ per h (remaining four subjects). The original infusion rate was chosen in consultation with the supplier (Genentech Inc., South San Francisco, CA) based on the existing safety data specifically to avoid the possibility of hypoglycemia. The change in rhIGF-I dose was necessitated by the development of asymptomatic sinus tachycardia after $\sim 24 \mathrm{~h}$ of infusion in the first two subjects. However, one of the subjects receiving the $10 \mu \mathrm{g} / \mathrm{kg}$ per h dose also developed sinus tachycardia. Frequent GH sampling (every $10 \mathrm{~min}$ ) was done from 0700 on day 3 (i.e., $19 \mathrm{~h}$ after rhIGF-I infusion was begun) to 1200 on day 4 . Similar to the baseline study, TRH $50 \mu \mathrm{g}$ i.v. was given at $0800 \mathrm{~h}$ on day 4 , and GHRH $0.33 \mu \mathrm{g} / \mathrm{kg}$ i.v. bolus was given at $1000 \mathrm{~h}$ on day 4, during rhIGF-I infusion. Plasma IGF-I was measured at 4-h intervals during saline infusion $(0800,1200,1600$, $2000,2400,0400,0800$, and $1200 \mathrm{~h}$ ), at half-hour to 1-h intervals for $4 \mathrm{~h}$ after the beginning of rhIGF-I infusion, at 4- $\mathrm{h}$ intervals thereafter until the end of rhIGF-I infusion, and at half-hour to 1-h intervals for $4 \mathrm{~h}$ after termination of rhIGF-I infusion. Plasma glucose was measured randomly on several occasions during saline and rhIGF-I infusions and at 30-min intervals for $1 \mathrm{~h}$ before and $2 \mathrm{~h}$ after the evening meal $(1800-2100 \mathrm{~h})$. During both saline and rhIGF-I infusions, plasma total thyroxine $\left(\mathrm{T}_{4}\right)$ was measured before TRH administration. Because of rare reports of cardiac arrhythmia with i.v. bolus thIGF-I injection, patients were on continuous electrocardiogram monitoring by telemetry. They were allowed to be ambulatory within the constraints placed by the frequent blood draws.

\section{Materials}

GHRH was purchased from Bachem California and prepared by the University of Michigan Investigational Drug Pharmacy to a concentration of $50 \mu \mathrm{g} / \mathrm{ml}$. rhIGF-I at a concentration of $5 \mathrm{mg} / \mathrm{ml}$ was a generous gift of Genentech Inc. and was diluted in $0.9 \%$ saline for infusion.

\section{Assays}

Growth hormone. Plasma GH concentrations were measured in duplicate by a chemiluminescent assay (Nichols Institute, San Juan Capistrano, CA). All samples from each particular subject were analyzed in the same assay. The sensitivity of the assay was conservatively estimated to be $0.01 \mu \mathrm{g} / \mathrm{liter}$. This point on the standard curve was $>10$ standard deviations away from the buffer control, and there was not one instance of the overlap between the replicates of these two points. The mean intra- and interassay coefficients of variation $(\mathrm{CV})$ were both below $5 \%$. rhIGF-I at a concentration of $1,000 \mu \mathrm{g} /$ liter did not interfere with the measurement of $\mathrm{GH}$ by the chemiluminescent assay (data not shown).

IGF-I. Total plasma IGF-I was measured by RIA (29) using rhIGFI (Mallinckrodt Specialty Chemicals, St. Louis, MO) as a standard and a polyclonal antibody generously donated by the National Hormone and Pituitary Distribution Program of the National Institute of Diabetes and Digestive and Kidney Diseases. Before the RIA, plasma samples were extracted with acid ethanol (29). Assay sensitivity was $<1 \mu \mathrm{g} /$ liter, and intraassay $\mathrm{CV}$ was $<10 \%$. All samples were assayed in triplicate, in a single assay.

TSH. Plasma TSH was measured in duplicate by a chemiluminescent assay (Ciba Corning, Medfield, MA). Assay sensitivity was $0.03 \mathrm{mU} /$ liter, and both intraassay and interassay CVs were below 7\%. All samples from a particular study were run in the same assay.

Hematology, serum chemistry, and $\mathrm{T}_{4}$ measurements were all performed in the Pathology Laboratories of the University of Michigan Medical Center using standard techniques.

\section{Data analysis}

Pulsatile GH secretion parameters were analyzed by the computer program Cluster using a power fit, a $t$-statistic of 2 , and a cluster size of $2 \times 2(30)$. Only computer-identified pulses that were greater in amplitude (nadir to peak) than $0.03 \mu \mathrm{g} /$ liter were considered as true pulses. This cutoff was established on the basis of Cluster analysis of 49 pseudoduplicates of a pooled plasma sample with a GH concentration of 0.03 $\mu \mathrm{g} /$ liter. In this series, Cluster analysis identified four pulses with a mean amplitude (nadir to peak) of $0.0225 \mu \mathrm{g} /$ liter. Thus, we regarded all Cluster-identified pulses with the amplitude below $0.03 \mu \mathrm{g} / \mathrm{liter}$ as indistinguishable from assay noise. Interpulse GH levels were defined as those segments identified by Cluster as nonpulsatile. Integrated total GH concentration (micrograms $\times$ minutes per liter) were calculated as the area under the GH versus time curve (AUC) using the trapezoidal rule. Integrated pulsatile $\mathrm{GH}$ concentration (micrograms $\times$ minutes per liter) was defined as the AUC during time segments identified as pulses by Cluster and greater in amplitude than $0.03 \mu \mathrm{g} /$ liter. Integrated nonpulsatile GH (micrograms $\times$ minutes per liter) was measured as integrated total minus the integrated pulsatile GH concentrations. The GH responses to GHRH and TSH responses to TRH were defined in terms of incremental rise (a difference between time zero concentration and maximal concentration after the test compound) as well as in terms of AUC.

Two-tailed paired Student's $t$ tests were used for statistical comparisons between groups. All results are presented as mean \pm standard error ( $\mathrm{M} \pm \mathrm{SE}$ ), and $P<0.05$ was considered significant. Data which were not normally distributed were logarithmically transformed before analy- 


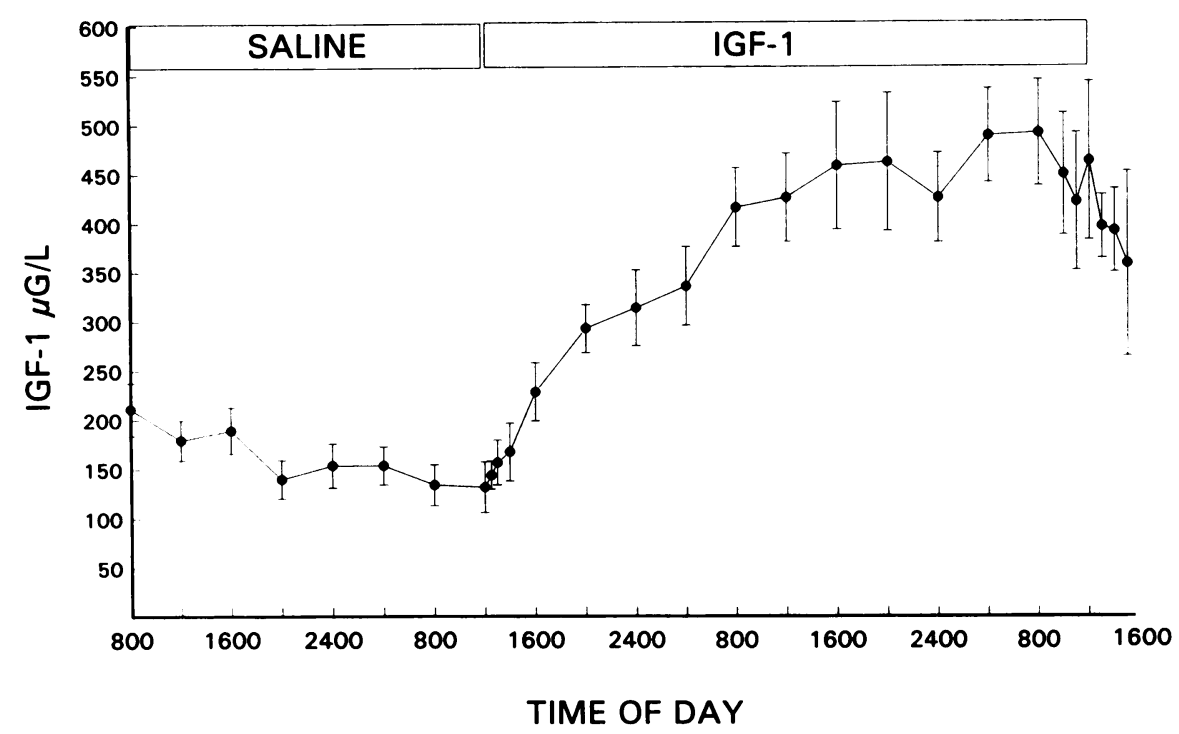

Figure 1. Plasma levels of total IGF-I before and during i.v. infusion of rhIGF-I ( 10 or 15 $\mu \mathrm{g} / \mathrm{kg}$ per $\mathrm{h}$ ). sis. In case of multiple comparisons, the overall per study error rate was limited by restricting the per comparison $P$ value to $<0.01(15)$.

\section{Results}

Total IGF-I plasma concentrations. During the saline infusion, plasma IGF-I concentrations were stable throughout the day, and the mean plasma IGF-I concentration was $163.5 \pm 9.3 \mu \mathrm{g} /$ liter (Fig. 1). During the rhIGF-I infusion, a steady rise in plasma IGF-I levels was seen within 1-2 h, the levels became significantly higher than the baseline at $4 \mathrm{~h}$, and a stable new steady state was achieved after $\sim 16 \mathrm{~h}$ of starting the infusion, before the onset of frequent $\mathrm{GH}$ sampling. In the first two volunteers who received $15 \mu \mathrm{g} / \mathrm{kg}$ per $\mathrm{h}$ of rhIGF-I, mean steady state IGF-I levels were $594.8 \pm 15.7 \mu \mathrm{g} /$ liter. In the remaining four volunteers who received the lower dose $(10 \mu \mathrm{g} / \mathrm{kg}$ per h $)$, mean steady state IGF-I levels were 377.9 $\pm 18.4 \mu \mathrm{g} /$ liter. Most of the discrete parameters of spontaneous $\mathrm{GH}$ secretion, $\mathrm{GH}$ responses to GHRH, and TSH responses to TRH (see below) during saline and rhIGF-I infusion in subjects 1 and 2 were within the range of the same parameters in subjects 3-6. Similarly, when the analysis was restricted only to subjects 3-6 who received rhIGF-I at $10 \mu \mathrm{g} / \mathrm{kg}$ per $\mathrm{h}$, the conclusions were identical to the analysis of the entire group of six subjects (data not shown). Since there were no differences in plasma GH and TSH dynamics or in plasma glucose levels between the two groups, all data were summarized for the final analysis. Overall, steady state IGF-I concentrations of $452.0 \pm 20.9 \mu \mathrm{g} /$ liter were achieved during the final $28 \mathrm{~h}$ of the infusion, i.e., at the time when both pulsatile GH profiles and dynamic GH and TSH responses were assessed. After termination of the infusion, there was a slow decline in the IGF-I levels, and $4 \mathrm{~h}$ later plasma IGF-I levels were $358.5 \pm 108.5 \mu \mathrm{g} /$ liter, i.e., $\sim 79 \%$ of the infusion value. This agrees well with the calculated half-life of IGF-I of $\sim 8-10 \mathrm{~h}(10)$.

Plasma glucose concentrations. rhIGF-I is well known to cause hypoglycemia, although this is rare in fed individuals at the doses used by us (10). Random plasma glucose levels did not differ between the saline and rhIGF-I infusions ( 104.7 \pm 2.6 vs $107.2 \pm 2.1 \mathrm{mg} / \mathrm{dl} ; P=0.72$ ). The preprandial (dinner time) glucose levels were slightly but significantly higher during rhIGF-I infusion $(91.2 \pm 3.3$ vs $100.5 \pm 2.8 \mathrm{mg} / \mathrm{dl}, P=0.043)$ but still in the normal range. The postprandial glucose levels $(115.8 \pm 3.6$ vs $125.0 \pm 4.9 \mathrm{mg} / \mathrm{dl} ; P=0.099)$ were similar during both the saline and rhIGF-I infusions.

Pulsatile GH profiles. During the baseline saline infusions, $\mathrm{GH}$ profiles were noted to be pulsatile in all patients. The mean 24-h GH concentration was $1.69 \pm 0.47 \mu \mathrm{g} /$ liter. The pulse frequency ranged between 4 and 10 per $24 \mathrm{~h}(7.8 \pm 0.9)$, and the mean amplitude of all pulses was $4.92 \pm 1.01 \mu \mathrm{g} /$ liter. The mean amplitude of the maximal pulse demonstrated by each patient was $21.50 \pm 4.23 \mu \mathrm{g} /$ liter. The values for $24-\mathrm{h}$ integrated $\mathrm{GH}$ levels (AUC) are also shown in Table I, along with the interpulse and nadir GH levels. The actual GH profiles of each of the subjects are shown in Fig. 2. Examples of pulsatile GH

Table I. Parameters of GH Secretion during Saline and IGF-I Infusions

\begin{tabular}{lccc}
\hline & Saline & IGF-I & $P$ value \\
\hline Plasma IGF-I $(\mu g /$ liter $)$ & $163.5 \pm 9.3$ & $452.0 \pm 20.9$ & 0.002 \\
Mean 24-h GH $(\mu g /$ liter $)$ & $1.69 \pm 0.47$ & $0.29 \pm 0.12$ & 0.011 \\
24-h AUC $(\mu g \times$ min/liter $)$ & & & \\
$\quad$ Total & $2428.6 \pm 678.5$ & $411.4 \pm 173.5$ & 0.011 \\
$\quad$ Pulsatile & $2368.3 \pm 650.9$ & $365.0 \pm 168.9$ & 0.009 \\
$\quad$ Nonpulsatile & $60.4 \pm 29.4$ & $47.0 \pm 13.5$ & 0.64 \\
Pulse frequency $(n / 24 h)$ & $7.8 \pm 0.9$ & $4.7 \pm 0.6$ & 0.006 \\
Pulse amplitude $(\mu g /$ liter $)$ & & & \\
$\quad$ Mean & $4.92 \pm 1.01$ & $1.12 \pm 0.39$ & 0.004 \\
$\quad$ Maximal & $21.50 \pm 4.23$ & $3.54 \pm 1.57$ & 0.002 \\
Interpulse GH $(\mu g /$ liter $)$ & $0.25 \pm 0.16$ & $0.07 \pm 0.02$ & 0.068 \\
Nadir GH $(\mu g /$ liter $)$ & $0.05 \pm 0.02$ & $0.045 \pm 0.017$ & 0.44 \\
GH response to GHRH & & & \\
$\quad$ Peak increment $(\mu g /$ liter $)$ & $14.85 \pm 5.22$ & $2.34 \pm 0.79$ & 0.002 \\
$\quad$ AUC $(\mu g \times$ min/liter $)$ & $691.2 \pm 248.4$ & $106.6 \pm 37.1$ & 0.0005 \\
& & & \\
\end{tabular}




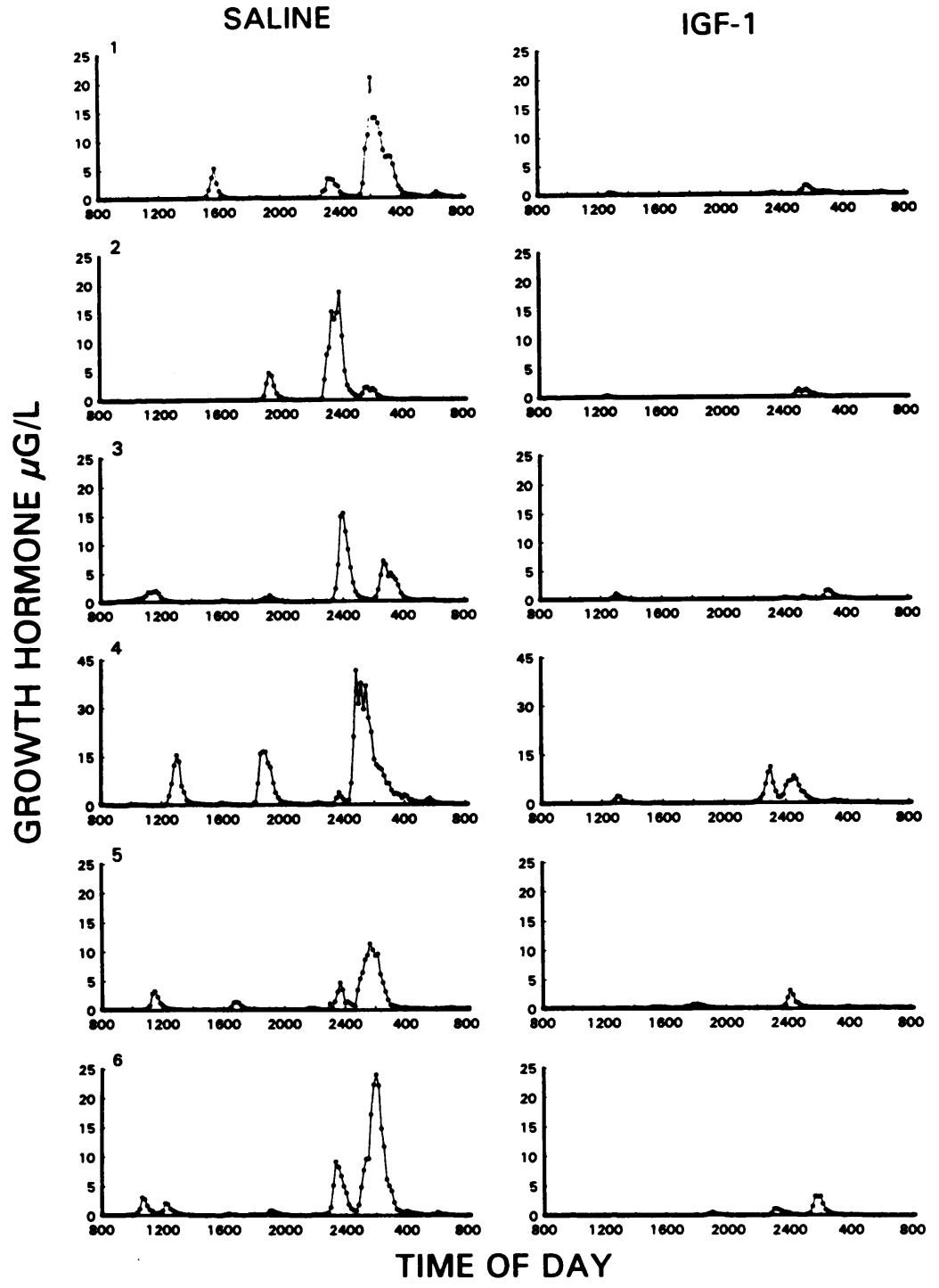

Figure 2. Plasma GH concentration profiles in six men during saline (left) and rhIGF-I (right) infusion. Subjects 1 and 2 received rhIGF-I at a rate of $15 \mu \mathrm{g} / \mathrm{kg}$ per $h$, and the rest were infused with rhIGF-I at a rate of $10 \mu \mathrm{g} / \mathrm{kg}$ per h. Plasma for GH was sampled every $10 \mathrm{~min}$ for $24 \mathrm{~h}$. profiles of subject 1 , who received rhIGF-I at $15 \mu \mathrm{g} / \mathrm{kg}$ per $\mathrm{h}$, and of subject 3 , who received rhIGF-I at $10 \mu \mathrm{g} / \mathrm{kg}$ per $\mathrm{h}$, are shown in Fig. 3 and are specifically enhanced to allow better visualization of small $\mathrm{GH}$ pulses and interpulse intervals.

During infusion of rhIGF-I, GH profiles were again noted to be pulsatile. The mean $24-\mathrm{h}$ GH level decreased to $0.29 \pm 0.12$ $\mu \mathrm{g} /$ liter $(P=0.011)$, i.e., $85 \pm 3 \%$ suppression. The pulse frequency ranged between three and seven per $24 \mathrm{~h}(4.7 \pm 0.6, P$ $=0.006$ vs saline infusion). The mean pulse amplitude was also decreased to $1.12 \pm 0.39 \mu \mathrm{g} / \operatorname{liter}(P=0.004)$ during rhIGFI infusion, which corresponds to a mean suppression of $77 \pm 4 \%$. The maximal pulse amplitude decreased to $3.54 \pm 1.57 \mu \mathrm{g} /$ liter $(P=0.002)$, i.e., $85 \pm 4 \%$ suppression. The total and pulsatile integrated GH levels were significantly suppressed during rhIGF-I infusion by $85 \pm 3(P=0.011)$ and $87 \pm 2 \%(P$ $=0.009$ ), respectively. The integrated nonpulsatile and nadir GH levels were not significantly different. The mean interpulse GH levels decreased almost fourfold from $0.25 \pm 0.16$ to $0.07 \pm 0.02 \mu \mathrm{g} /$ liter, and there was a trend for statistical significance $(P=0.068)$. The overall $(\mathrm{M} \pm \mathrm{SE}) \mathrm{GH}$ concentration profiles in all six subjects during saline and rhIGF-I infusions are shown in Fig. 4.

GH response to GHRH (Fig. 5). Administration of exogenous $\mathrm{GHRH}$ at $0.33 \mu \mathrm{g} / \mathrm{kg}$ during saline infusion produced a GH peak to a maximum of $14.85 \pm 5.22 \mu \mathrm{g} /$ liter. During the infusion of rhIGF-I, the GH response to GHRH was attenuated to $2.34 \pm 0.79 \mu \mathrm{g} /$ liter $(P=0.002)$. This corresponds to a mean suppression of $81 \pm 5 \%$. The comparison of GH AUCs reached similar conclusions $(576.0 \pm 226.7$ vs $88.8 \pm 33.9 \mu \mathrm{g} \times \mathrm{min} /$ liter; $81 \pm 3 \%$ suppression; $P=0.0005$ ).

TSH response to TRH (Fig. 6). During saline infusion, baseline TSH concentrations were $1.22 \pm 0.15 \mathrm{mU} /$ liter, and the mean increment of TSH was $4.68 \pm 0.46 \mathrm{mU} /$ liter (baseline to maximum excursion). During rhIGF-I infusion, both baseline TSH concentrations $(0.61 \pm 0.07 \mathrm{mU} /$ liter $)$ as well as TSH increment to TRH $(3.33 \pm 0.68 \mathrm{mU} /$ liter $)$ were significantly suppressed ( $P=0.04$ and 0.03 , respectively). The incremental TSH rise was suppressed by $31 \pm 11 \%$. Similar data were obtained when integrated TSH responses (AUC) were analyzed (193.3 \pm 27.6 vs $108.4 \pm 21.3 \mathrm{mU} \times \mathrm{min} /$ liter, $44 \pm 9 \%$ suppres- 

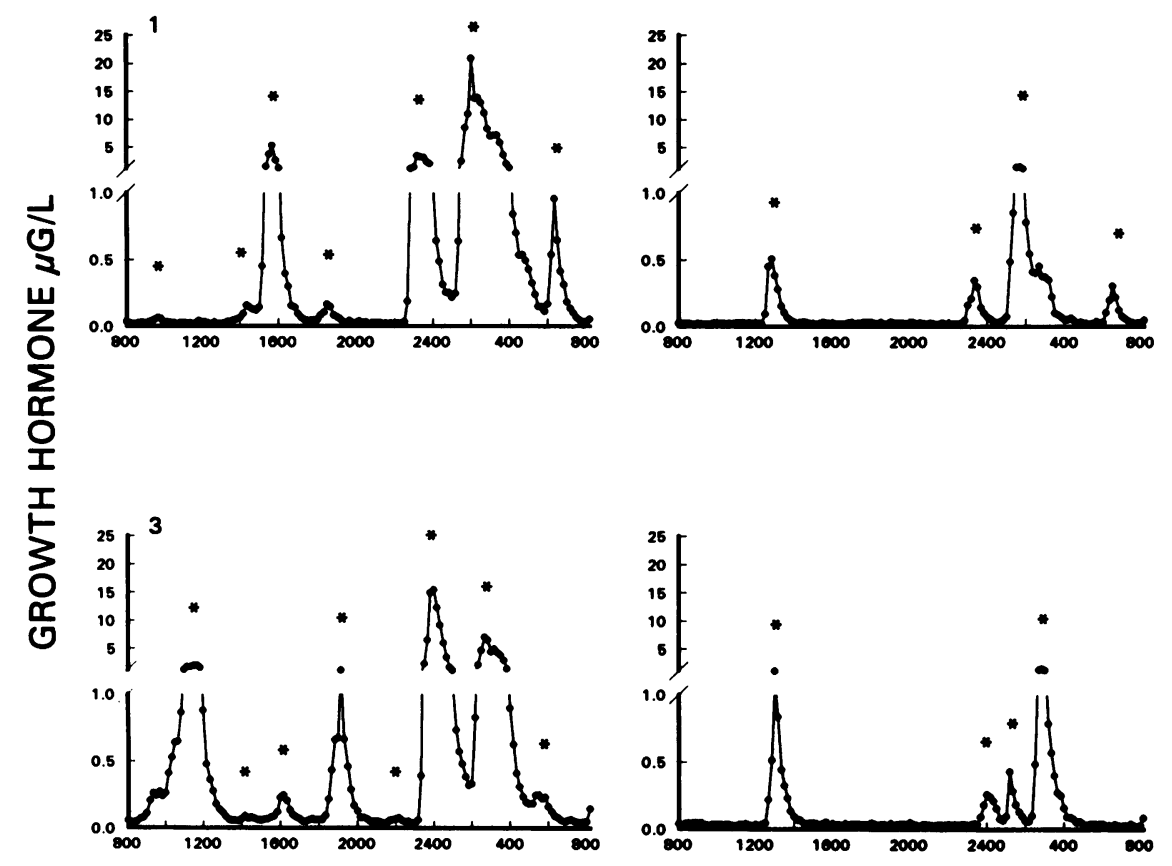

TIME OF DAY
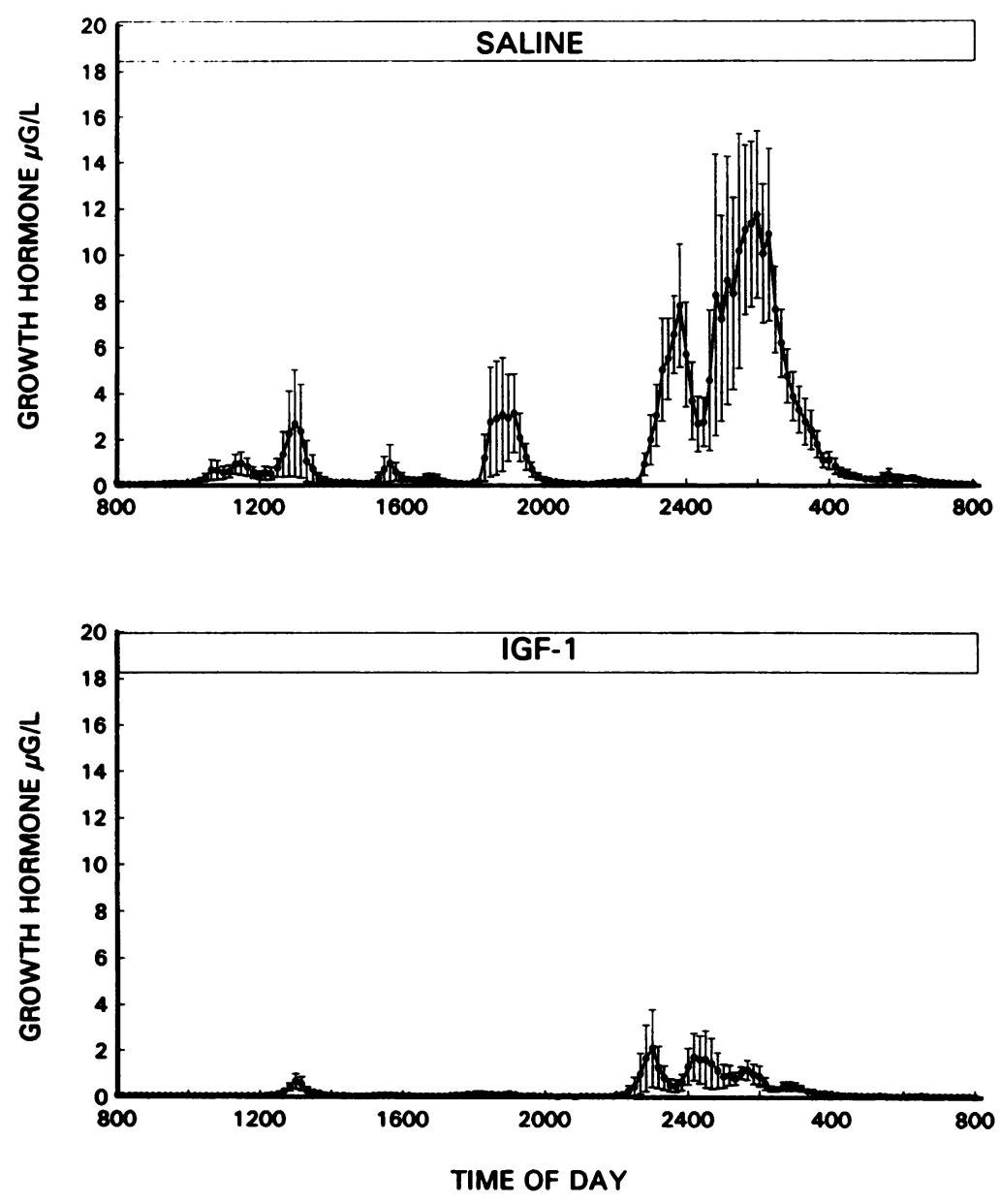

Figure 3. Plasma GH concentration profiles in subjects 1 (top) and 3 (bottom) during saline and rhIGF-I infusions. The $y$-scales were broken to allow better visualization of the low GH range. Asterisks mark significant GH pulses.
Figure 4. A composite picture of plasma GH concentration profiles $(\mathrm{M} \pm \mathrm{SE})$ in all six subjects during saline (top) and rhIGF-I (bottom) infusions. 


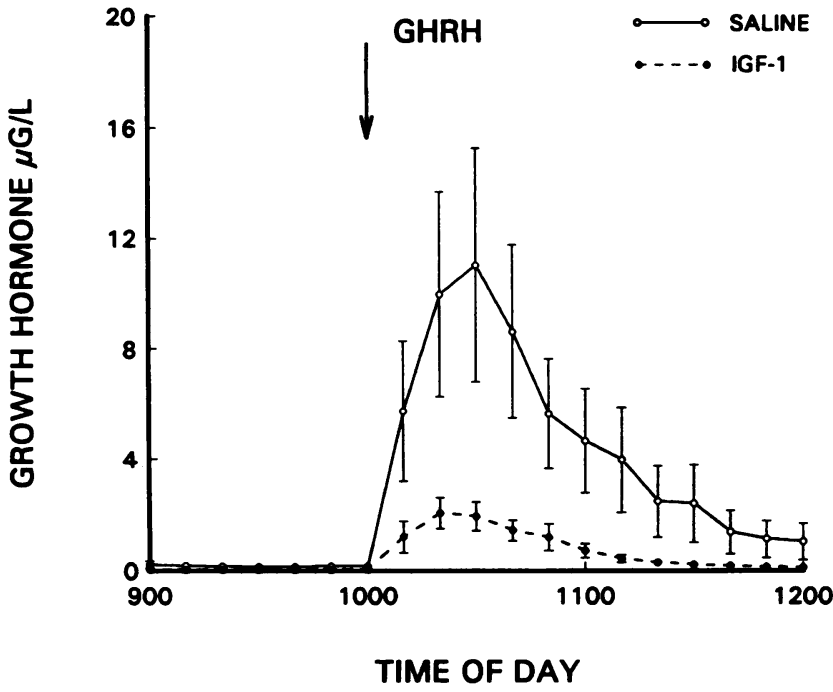

Figure 5. Plasma GH responses to GHRH ( $0.33 \mu \mathrm{g} / \mathrm{kg}$ i.v. $)$ during saline and rhIGF-I infusions $(\mathrm{M} \pm \mathrm{SE})$.

sion, $P=0.01)$. The mean serum $\mathrm{T}_{4}$ level during saline $(7.1 \pm 0.4 \mu \mathrm{g} / \mathrm{dl})$ was not significantly different from the level during rhIGF-I infusion ( $7.5 \pm 0.6 \mu \mathrm{g} / \mathrm{dl}, P>0.05)$.

\section{Discussion}

In this study, administration of rhIGF-I increased plasma peptide levels approximately threefold, and this was followed by an $\sim 85 \%$ suppression of total GH concentrations. Thus, even in a fed state, rhIGF-I exerts a powerful negative feedback on $\mathrm{GH}$ secretion. This was accounted for almost entirely by the attenuation of the pulsatile GH secretion component ( 87\% suppression). Three potential mechanisms (alone or in combination) can be involved in this effect: $(a)$ direct pituitary inhibi-

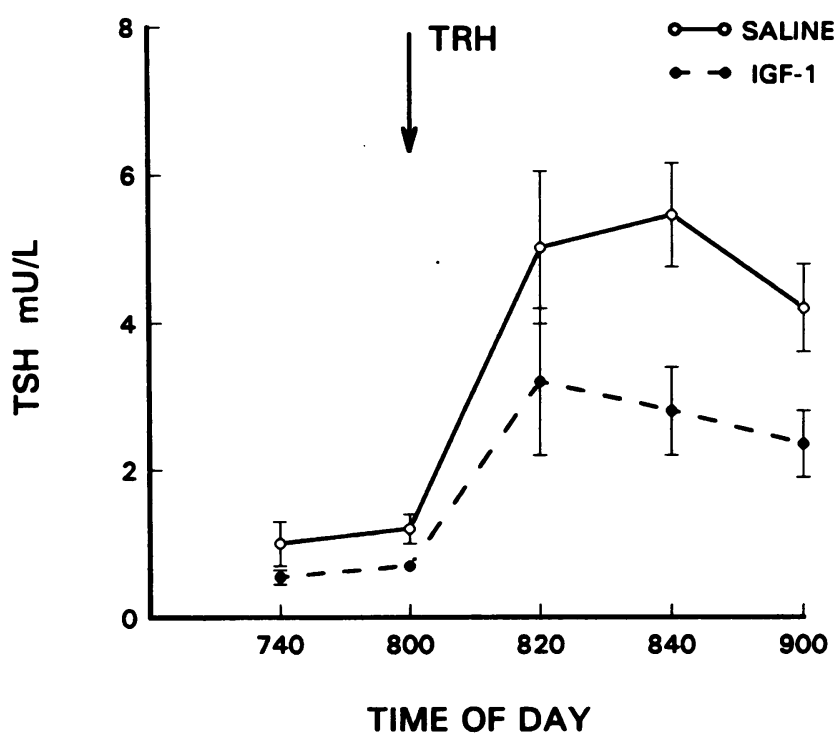

Figure 6. Plasma TSH responses to TRH ( $50 \mu \mathrm{g}$ i.v.) during saline and rhIGF-I infusions $(\mathrm{M} \pm \mathrm{SE})$. tion of GH secretion $(6,7),(b)$ suppression of GHRH secretion (31), or (c) stimulation of SRIF release (6).

Both animal $(1,2,16)$ and human (32) data have shown that periodic $\mathrm{GH}$ pulses are largely dependent on phasic GHRH release. Thus, a decrease in the apparent GH pulse frequency during rhIGF-I infusion may be conceivably attributed to attenuated GHRH secretion. A direct suppressive effect of rhIGFI on hypothalamic GHRH synthesis and secretion has been documented in vitro using rat hypothalamic slices (31) and in vivo using intracerebroventricular rhIGF-I infusion in rats (5), although a systemic administration of rhIGF-I was incapable of altering hypothalamic GHRH mRNA content (5). However, the $40 \%$ decline in $\mathrm{GH}$ pulse frequency observed in this study is not sufficient by itself to explain the $80 \%$ attenuation of the total GH secretion. Since any pulse detection program requires a certain minimal elevation of hormone concentration above the baseline as a prerequisite for definition of a pulse, it is likely that the apparent decline in GH pulse frequency during rhIGFI infusion was due to the suppressive effect of rhIGF-I upon spontaneous GH pulse amplitude and GH responsiveness to GHRH. Taking into account the $\sim 80 \%$ suppressive effect of rhIGF-I on pulse amplitude, any GH pulse with the intended amplitude of below $0.15 \mu \mathrm{g} /$ liter would be expressed as a $\mathrm{GH}$ rise of $<0.03 \mu \mathrm{g} /$ liter, i.e., indistinguishable from assay noise. Indeed, during the baseline study, an average of $1.5 \pm 0.5 \mathrm{GH}$ pulses per subject had amplitudes below the $0.15 \mu \mathrm{g} /$ liter cutoff range. Correcting for these pulses, only $6.3 \pm 1.1$ pulses $/ 24 \mathrm{~h}$ would have remained "visible" during rhIGF-I infusion, and the difference in pulse frequency between the basal and the IGF-I stages of the protocol would vanish $(P=0.15)$. Thus, elimination of the stimulatory influence of GHRH is an unlikely mechanism of IGF-I negative feedback. Instead, one would have to postulate the involvement of a suppressive mechanism, such as a direct pituitary effect of IGF-I or a stimulation of hypothalamic SRIF secretion.

The conclusive differentiation between these two mechanisms would require estimation of the hypothalamic SRIF output in the pituitary-portal vessels. This approach is, of course, impossible in humans. Therefore, we used the measurement of basal and TRH-stimulated TSH secretion as an independent marker of hypothalamic SRIF secretion. IGF-I does not influence TSH secretion from the pituitary in vitro (6), but TSH is readily suppressed by SRIF (33-35). The observed suppression of both basal and TRH-induced TSH levels suggests that hypothalamic SRIF secretion was indeed augmented by rhIGF-I infusion. Our data cannot exclude the possibility that, at least in part, the suppressive effect of rhIGF-I upon GH secretion is expressed directly at the level of pituitary somatotrophs. This mechanism was documented clearly in vitro using normal rat pituitary cells $(6,7)$ and human somatotropinomas $(9)$. On the other hand, an increase in hypothalamic SRIF secretion capable of suppressing TSH secretion by $44 \%$ may by itself be sufficient to completely account for the $80 \%$ suppression of $\mathrm{GH}$ secretion. Indeed, in the study by Williams et al. (36), SRIF infusion, at a rate of $50 \mu \mathrm{g} / \mathrm{h}$ that increased plasma SRIF 20-fold (still presumably in the physioslogic range), suppressed TSH response to TRH by $43 \pm 5$ and GH response to GHRH by $78 \pm 5 \%$, respectively. These values are remarkably similar to the relative degrees of inhibition of both hormones in our study during rhIGF-I infusion. Thus, the existence of an additional pituitary mechanism of IGF-I action needs not be invoked. Since tonic 
secretion of SRIF is believed to maintain low interpulse GH concentrations $(1,2)$, a decline in this parameter would be expected if rhIGF-I indeed stimulated SRIF secretion from the hypothalamus. While we were unable to document such an effect statistically, a strong trend was actually present. Additional studies using a larger number of subjects will be needed to clarify this point.

$\mathrm{GH}$ by itself is also a powerful negative feedback regulator of its own secretion (37-39). It appears to exert its effect both by stimulating SRIF synthesis and secretion and by suppressing GHRH synthesis and secretion (40). In the present study, GH secretion was suppressed during rhIGF-I infusion, and this by itself would be expected to result in high GHRH and low SRIF milieu. Since our data suggest strongly that rhIGF-I causes stimulation of SRIF secretion, the potential effect of lowered GH must have been minimal at best and grossly outweighed by the influence of high circulating IGF-I.

In conclusion, we are presenting the first detailed account of the effects of systemically administered rhIGF-I upon parameters of GH pulsatility in normal, nutritionally uncompromised men. Our data indicate that a threefold increase in circulating IGF-I concentrations powerfully suppresses total GH output, mainly at the expense of attenuated GH pulse amplitude. This is accompanied by a proportionate decline in pituitary sensitivity to GHRH and by significant suppression of basal and TRHstimulated TSH secretion. This constellation of findings suggests that the main target of the IGF-I negative feedback in humans may be expressed at the level of hypothalamic SRIF neurons. This is supported further by the trend of the interpulse GH levels to decline during rhIGF-I infusion. While some decline in GH pulse frequency might suggest rhIGF-I-induced attenuation of GHRH secretion, it more likely reflects high SRIF milieu with the resultant blockade of the pituitary somatotroph responses to an unchanged GHRH pulsatility.

\section{Acknowledgments}

The authors wish to thank the National Hormone and Pituitary Distribution Program of the National Institute of Diabetes and Digestive and Kidney Diseases for donation of the polyclonal IGF-I antibody; Dr. Neil Gesundheit of Genentech Inc. for the generous gift of rhIGF-I; the Reproductive Sciences Program of the University of Michigan for technical assistance; and the nurses and staff of the University of Michigan Clinical Research Center.

This work was supported by the Veterans Affairs Medical Research Service and National Institutes of Health grants R29-DK38449 (A. L. Barkan) and MO-1-RR-42 (CRC).

\section{References}

1. Plotsky, P. M., and W. Vale. 1985. Pattern of growth hormone releasing factor and somatostatin secretion into the hypophyseal-portal circulation of the rat. Science (Wash. DC). 230:461-463.

2. Tannenbaum, G. S. 1989. Interrelation of growth hormone releasing hormone and somatostatin in the regulation of growth hormone secretion. In Hormonal Regulation of Growth. H. Freich and M. O. Thorner, editors. Raven Press, New York. 1-17.

3. Tannenbaum, G. S., H. J. Guyda, and B. I. Posner. 1983. Insulin-like growth factors: a role in growth hormone negative feedback and body weight regulation via brain. Science (Wash. DC). 220:77-79.

4. Abe, H., M. E. Molitch, J. J. Van Wyk, and L. E. Underwood. 1983. Human growth hormone and somatomedin-C suppress the spontaneous release of growth hormone in unanesthetized rats. Endocrinology. 113:1319-1324.

5. Sato, M., and L. A. Frohman. 1993. Differential effects of central and peripheral administration of growth hormone $(\mathrm{GH})$ and insulin-like growth factor on hypothalamic GH-releasing hormone and somatostatin gene expression in GHdeficient dwarf rats. Endocrinology. 133:793-799.

6. Berelowitz, M., M. Szabo, L. A. Frohman, S. Firestone, L. Chu, and R. L. Hintz. 1981. Somatomedin-C mediates growth hormone negative feedback by effects on both the hypothalamus and pituitary. Science (Wash. DC). 212:12791281 .

7. Morita, S., S. Yamashita, and S. Melmed. 1987. Insulin-like growth factorI action on rat anterior pituitary cells: effects of intracellular messengers on growth hormone secretion and messenger RNA levels. Endocrinology. 121:2000-2006.

8. Thomas, G. B., J. T. Cummins, J. Francis, A. W. Sudbury, P. I. McCloud, and I. J. Clarke. 1991. Effect of restricted feeding on the relationship between hypophysial portal concentrations of growth hormone $(\mathrm{GH})$ releasing factor and somatostatin, and jugular concentrations of $\mathrm{GH}$ in ovariectomized ewes. Endocrinology. 128:1151-1158.

9. Yamashita, S., M. Weiss, and S. Melmed. 1986. Insulin-like growth factor I regulates growth hormone secretion and messenger ribonucleic acid levels in human pituitary tumor cells. J. Clin. Endocrinol. \& Metab. 63:730-735.

10. Vaccarello, M. A., F. B. Diamond, Jr., J. Guevara-Aquirre, A. L. Rosenbloom, P. J. Fielder, S. Gargaskey, P. Cohen, K. Wilson, and R. G. Rosenfeld. 1993. Hormonal and metabolic effects and pharmacokinetics of recombinant insulin-like growth factors-I in growth hormone receptor deficiency syndrome/Laron syndrome. J. Clin. Endocrinol. \& Metab. 77:273-280.

11. Straus, D. S., and C. N. Takemoto. 1990. Effect of fasting on insulin-like growth factor I (IGF-I) and growth hormone receptor mRNA levels and IGF-I transcription in rat liver. Mol. Endocrinol. 4:91-100.

12. Clemmons, D. R., A. Klibanski, L. E. Underwood, J. W. McArthur, E. C. Ridgway, I. Z. Beitins, and J. J. Van Wyk. 1981. Reduction of plasma immunoreactive somatomedin-C during fasting in humans. J. Clin. Endocrinol. \& Metab. 53:1247-1250.

13. Ho, K. Y., J. D. Veldhuis, M. L. Johnson, R. Furlanetto, W. S. Evans, K. G. M. M. Alberti, and M. O. Thorner. 1988. Fasting enhances growth hormone secretion and amplifies the complex rhythms of growth hormone secretion in man. J. Clin. Invest. 81:968-975.

14. Ho, P. J., R. DeMott-Friberg, and A. L. Barkan. 1992. Regulation of pulsatile growth hormone secretion by fasting in normal subjects and patients with acromegaly. J. Clin. Endocrinol. \& Metab. 75:812-819.

15. Hartman, M. L., P. E. Clayton, M. L. Johnson, A. Celniker, A. J. Perlman, K. G. M. M. Alberti, and M. O. Thorner. 1993. A low dose euglycemic infusion of recombinant human insulin-like growth factor I rapidly suppresses fastingenhanced pulsatile growth hormone secretion in humans. J. Clin. Invest. 91:24532462 .

16. Frohman, L. A., T. R. Downs, I. J. Clarke, and G. B. Thomas. 1990 Measurement of growth hormone-releasing hormone and somatostatin in hypothalamic-portal plasma of unanesthetized sheep. Spontaneous secretion and response to insulin-induced hypoglycemia. J. Clin. Invest. 86:17-24.

17. Martha, P. M., Jr., A. D. Rogol, J. D. Veldhuis, J. R. Kerrigan, D. W. Goodman, and R. M. Blizzard. 1989. Alterations in the pulsatile properties of circulating growth hormone concentrations during puberty in boys. J. Clin. Endocrinol. \& Metab. 69:563-570.

18. Faria, A. C. S., L. W. Bekenstein, R. A. Booth, Jr., V. A. Vaccaro, C. M. Asplin, J. D. Veldhuis, M. O. Thorner, and W. S. Evans. 1992. Pulsatile growth hormone release in normal women during the menstrual cycle. Clin. Endocrinol. 36:591-596.

19. Ho, K. Y., W. S. Evans, R. M. Blizzard, J. D. Veldhuis, G. R. Merriam, E. Samojlik, R. Furlanetto, A. D. Rogol, D. L. Kaiser, and M. O. Thorner. 1987. Effects of sex and age on the 24 hour profile of growth hormone secretion in man: importance of endogenous estradiol concentrations. J. Clin. Endocrinol. \& Metab. 64:51-58.

20. Williams, T., M. Berelowitz, S. N. Jaffe, M. O. Thorner, J. Rivier, W. Vale, and L. A. Frohman. 1984. Impaired growth hormone responses to growth hormone releasing factor in obesity. N. Engl. J. Med. 311:1403-1407.

21. Asplin, C. M., A. C. Faria, E. C. Carlsen, V. A. Vaccaro, R. E. Barr, A Iranmanesh, M. M. Lee, J. D. Veldhuis, and W. S. Evans. 1989. Alterations in the pulsatile mode of growth hormone release in men and women with insulin dependant diabetes mellitus. J. Clin. Endocrinol. \& Metab. 69:239-245.

22. Zadik, Z., S. A. Chalew, and A. Kowarski. 1992. The definition of a spontaneous growth hormone $(\mathrm{GH})$ peak: studies in normally growing and $\mathrm{GH}$ deficient children. J. Clin. Endocrinol. \& Metab. 74:801-805.

23. Barkan, A. L., S. E. Stred, K. Reno, M. Markovs, N. J. Hopwood, R. P. Kelch, and I. Z. Beitins. 1989. Increased GH pulse frequency in acromegaly. $J$. Clin. Endocrinol. \& Metab. 69:1225-1233.

24. Hartman, M. L., J. D. Veldhuis, M. L. Vance, A. C. Faria, R. W. Furlanetto, and M. O. Thorner. 1990. Somatotropin pulse frequency and basal concentrations are increased in acromegaly and are reduced by successful therapy. J. Clin. Endocrinol. \& Metab. 70:1375-1384.

25. Snyder, P. J., and R. D. Utiger. 1972. Response to thyrotropin-releasing hormone (TRH) in normal men. J. Clin. Endocrinol. \& Metab. 34:380-385.

26. Vance, M. L., J. L. Borges, D. L. Kaiser, W. S. Evans, R. Furlanetto, J. L. 
Thominet, L. A. Frohman, A. D. Rogol, R. M. MacLeod, S. Bloom, et al. 1984 Human pancreatic-tumor growth hormone releasing factor: dose response relationship in normal man. J. Clin. Endocrinol. \& Metab. 58:838-844.

27. Gelato, M. C., O. H. Pescovitz, F. Cassoria, D. L. Loriaux, and G. R. Merriam. 1984. Dose response relationships for the effect of growth hormone releasing factor (1-44) $-\mathrm{NH}_{2}$ in young adult men and women. J. Clin. Endocrinol. \& Metab. 59:197-201.

28. Van Cauter, E., A. Caufriez, M. Kerkhofs, A. Van Onderbergen, M. O Thorner, and G. Copinschi. 1992. Sleep, awakenings, and insulin-like growth factor-I modulate the growth hormone response to growth hormone releasing hormone. J. Clin. Endocrinol. \& Metab. 74:1451-1459.

29. Daughaday, W. H., I. K. Mariz, and S. L. Blethen. 1980. Inhibition of access of bound somatomedin to membrane receptor and immunobinding sites: a comparison of radioreceptor and radioimmunoassay of somatomedin in native and acid ethanol extracted serum. J. Clin. Endocrinol. \& Metab. 51:781-788.

30. Veldhuis, J. D., and M. L. Johnson. 1986. Cluster analysis: a simple, versatile and robust algorithm for endocrine pulse detection. Am. J. Physiol. 250:E486-E493.

31. Shibasaki, T., N. Yamauchi, M. Hotta, A. Masuda, T. Imaki, H. Demura, N. Ling, and K. Shizume. 1986. In vitro release of growth hormone-releasing factor from rat hypothalamus: effect of insulin-like growth factor I. Regul. Pept. 15:47-53.

32. Jaffe, C. A., R. DeMott Friberg, and A. L. Barkan. 1993. Suppression of growth hormone ( $\mathrm{GH}$ ) secretion by a selective GH-releasing hormone (GHRH) antagonist. Direct evidence for involvement of endogenous GHRH in the generation of GH pulses. J. Clin. Invest. 92:695-701.
33. Vale, W., C. Rivier, P. Brazeau, and R. Guillemin. 1975. Effects of somatostatin on the secretion of thyrotropin and prolactin. Endocrinology. 95:968-977.

34. Weeke, J., A. P. Hansen, and K. Lundaek. 1975. Inhibition by somatostatin of basal levels of serum thyrotropin in normal men. J. Clin. Endocrinol. \& Metab. 41:168-171.

35. Lucke, C., B. Hof $f$ ken, and A. von zur Muhlen. 1975. The effect of somatostatin on TSH levels in patients with primary hypothyroidism. J. Clin. Endocrinol. \& Metab. 41:1082-1084.

36. Williams, T. C., M. Kelijman, W. C. Crelin, T. R. Downs, and L. A. Frohman. 1988. Differential effects of somatostatin (SRIH) and a SRIH analog SMS 201-995 on the secretion of growth hormone and thyroid stimulating hormone in man. J. Clin. Endocrinol. \& Metab. 66:39-45.

37. Chihara, K., N. Minamitani, H. Kaji, A. Arimura, and T. Fujita. 1981. Intraventricularly injected growth hormone stimulates somatostatin release into rat hypophyseal portal blood. Endocrinology. 109:2279-2281.

38. Berelowitz, M., S. L. Firestone, and L. A. Frohman. 1981. Effects of growth hormone excess and deficiency on hypothalamic somatostatin content and release and on tissue somatostatin distribution. Endocrinology. 109:714-719.

39. Robbins, R. J., J. W. Leidy, Jr., and R. M. Landon. 1985. The effects of growth hormone, prolactin, corticotrophin, and thyrotrophin on the production and secretion of somatostatin by hypothalamic cells in vitro. Endocrinology. 117:538-543.

40. Chomczynski, P., T. R. Downs, and L. A. Frohman. 1988. Feedback regulation of growth hormone releasing hormone gene expression by growth hormone in the rat hypothalamus. Mol. Endocrinol. 2:236-241. 